\title{
IMPACT OF FDI ON LITHUANIAN ECONOMY: INSIGHT INTO DEVELOPMENT OF MAIN ECONOMIC ACTIVITIES
}

\author{
Manuela Tvaronavičiené $\dot{1}^{1}$ Virginija Grybaitè ${ }^{2}$ \\ Vilnius Gediminas Technical University, Sauletekio al. 11, 10223 Vilnius, Lithuania, \\ e-mail: 'Imanuela@vv.vgtu.lt; ${ }^{2} v i r g i @ v v . v g t u . l t$ \\ Received 7 February 2007; accepted 6 March 2007
}

\begin{abstract}
Aim of the paper is to estimate impact of foreign direct investment (FDI) on growth of economy in Lithuania. In order to detect specifics of development of main economic activities, differences in structure of FDI and structure of GDP of host economy are being juxtaposed, FDI intensity indicator in main economic activities elaborated. Authors test if different levels of penetration of foreign capital into certain economic activities serve as important factor affecting their economic growth. Research is being developed further by making assumption about higher concentration of FDI intensive economic activities. Higher concentration in that context would be interpreted as possible crowding out of local business firms from FDI intensive industries.
\end{abstract}

Keywords: FDI, economic growth, economic structure, Lithuania, transition process.

\section{Introduction - theoretical approach}

Foreign direct investment (FDI) is usually rather unanimously treated as important factor of economic growth. There is a lot of scientific literature elaborating various facets of relationship between FDI and economic growth, especially in transition countries.

Studies on the FDI role in host economy's development pattern could be attributed to several groups. The first group of authors argue that FDI is an important source of capital, which complements domestic private investment. It is usually associated with new job opportunities and enhancement of technology transfer, increase of exports. Thereby, these authors believe FDI boosts overall economic growth in host country (Balasubramanyam et al. (1999), Borenztein et al. (1998), Olofsdotter (1998), Zhang (2001), Bengoe and SanchezRobles (2003), Basu, Chakraborty and Reagle (2003), De Mello (1997, 1999). Balasubramanyam analyzes specific conditions, in which FDI affects economic growth in developing economies. Using cross-sectional data and OLS regressions he finds that FDI has a positive effect on economic growth in host countries using an export promoting strategy but not in countries using an import substitution strategy. Using cross-sectional data Olofsdotter finds that an increase in the stock of FDI is positively related to growth and that the effect is stronger on host countries with a higher level of institutional capability as measured by the degree of property rights protection and bureaucratic efficiency in the host country. Bengoa and Sanchez-Robles (2003) investigate the relationship between FDI, economic freedom and economic growth using panel data for Latin America. Comparing fixed and random effects estimations they conclude that FDI has a significant positive effect on host country economic growth. Zhang (2001) and Choe (2003) analyse the causality between FDI and economic growth. Zhang uses data for 11 developing countries in East Asia and Latin America. Using cointegration and Granger causality tests, Zhang (2001) finds that in five cases economic growth is enhanced by FDI, but that host country conditions such as trade regime and macroeconomic stability are important. The findings of De Mello suggest that the direction of causation between FDI and growth may also depend on existing factor endowments and scale effects, such that larger economies are more attractive to FDI than 
smaller ones. In short, the direction of causality between FDI and growth depend on the determinants of FDI and specific conditions, in which inflows of foreign capital take place. Karbasi, Mohamadi, Ghofrani (2005) derived model from a production function, in which the level of a country's productivity depends on FDI, trade, domestic investment, human capital, and initial gross domestic product (GDP) per capita. To conclude, FDI by that group of authors is being considered as significant driving force of economic growth but array of other factors might affect economic growth simultaneously. We are basing our particular research on the latter generalization: FDI might be an important factor of economic growth but we need to try to estimate quantitatively both impact on countries' GDP growth and on growth of separate GDP compounding industries.

If to return to vast academic sources on FDI and economic relationship, we need to emphasise opinion about negative impact of FDI on the growth of host economy, or related views claiming that the relationship between growth and FDI is not significant. As the main distinguished negative aspects of FDI the following phenomena are listed: the repatriation of foreign profits (Bhagwati, 1973; Singer, 1950 and Prebisch, 1968); the speed up of inflation due to increase of host country's money supply and through that, increase of private consumption and growth of import (Drabek and Griffith-Jones, 1998). According to Drabek and Griffith-Jones substantial inflows of foreign capital increase a host country's money supply and through that, private consumption increases. This, in turn, leads to import growth and speeds up inflation. Drabek and Griffith-Jones indicate that large foreign direct investment inflows might even increase a country's foreign debt, because they indicate its economic success and therefore make borrowing from abroad easier; and negative trade balance, especially in the case of marketseeking investments (Brouthers, Werner, and Wilkinson, 1996). Early studies on FDI, such as Singer (1950) and Prebisch (1968) claimed that the target countries of FDI receive very few benefits, because most benefits are transferred to the multinational company's country. Taking into account arguments presented above, in our paper we aim to detect by means of statistical analysis the actual relationship between inflows of foreign capital, expressed by FDI stock and economic growth, reflected by indicator of GDP.

To go further, we found that some authors indicate that the inflows of FDI into different economic sectors exert different effects on economic growth (Alfaro, 2002; Hirschman, 1958). Hirschman (1958) emphasizes that not all sectors have the same potential to absorb foreign technology or to create linkages with the rest of the economy. He noted, for example, "linkages are weak in agriculture and mining." He warned that in the absence of linkages, foreign investments could have limited effect on spurring growth in an economy. We develop further this theoretical approach by raising question about impact of separately taken inflows of foreign capital into certain economic activities, and asking how much growth of industries comprising GDP is being determined by FDI share directed concretely to those industries.

Presented approach might lead to important policy implications of Lithuania, as transition country.

At the current moment the opinion that FDI is beneficial and undoubtedly boosts economic growth still prevails. That opinion is straightforwardly expressed in "Long-term Economic Development Strategy". Lithuanian government strives to attract foreign investment, regardless to which sectors of economic activity these investments will be directed. Presented research might pour some light on relationships between FDI and growth of output in separate economic activities. That would lead to a device for more efficient economic policy of FDI stimulation.

\section{Quantitative estimation of FDI impact on economic growth of Lithuania}

With reference to analysed literature, the following assumptions have been tested. The first assumption is that there might be positive relationship between FDI and GDP growth in Lithuania. Correlation analysis, where the foreign direct investment stock was denoted as independent variable and gross domestic product was denoted as dependent variable, has been performed. GDP data was collected from Lithuanian quarterly GDP account (Lithuanian Department of Statistics). The period of analysis is 2000-2006. The results of correlation analysis indicated that correlation coefficient $\mathrm{R}$ equals 0.98 , estimated $\mathrm{t}$ statistics equals 10.53 , and it is bigger than tabulated t (2.78) by 4 degrees of freedom using $5 \%$ level of significance. It means that there is strong and positive relation between GDP and FDI stock. Therefore we could state that increasing amounts of FDI stock induce Lithuanian economic growth. We can claim that evidence from Lithuania compliments the results of empirical researches made by authors Balasubramanyam et al., Borenztein et al., Olofsdotter, Zhang, Bengoe and Sanchez-Robles, Basu,Charboty and Reagle and others, who argued generally positive FDI impact on economic growth. 


\section{FDI by economic activities and development of those economic activities}

Country's economy is a composite of various sectors of activities, named economic activities, and flows of FDI to these economic activities usually vary a lot. For analytical reasons it is important to detect, which sectors of economic activities attract what share of cumulative FDI, and, those, which have the greatest impact on economic growth. FDI activities were ranked, according to NACE codes. NACE codes represent the statistical classification of economic activities within the European Union, which serves as a basis for compiling statistics on the production, factors of production (labor, raw materials, energy, etc.), fixed capital formation operations and financial operations of firms and other entities. In Fig. 1 data on FDI stock, GDP and FDI/GDP ratio in Lithuania in the year 2006 by economic activities is being juxtaposed.

Data (Fig. 1) indicates that the greatest share of FDI stock goes to manufacturing (39.57\%); wholesale and retail trade, repair of motor vehicles, motorcycles and personal and household goods (11.03\%); financial intermediation (12.36\%); and transport and storage $(1.43 \%)$, post and telecommunications $(12.25 \%)$. The lowest percentage of FDI stock was estimated in education, health and social work $(0.12 \%)$; agriculture, hunting, forestry and fishing $(0.70 \%)$; mining and quarrying $(0.66 \%)$; construction $(1.18 \%)$; hotels and restaurants $(0.88 \%)$. These five sectors together compound only $3.54 \%$ of FDI.
Aiming to perform analysis of FDI by economic activity, the criterion of FDI intensity was selected. The FDI intensity was denoted as ratio of FDI directed to a particular sector of economy and GDP generated by that sector, expressed in percentage terms (i.e. relationship between inward FDI stocks by economic activity, million LTL, and GDP at current prices by economic activity, million LTL). In order to find out which economic activities are most attractive for investment and which are least attractive, criteria of "attractive" and "unattractive" economic activities were selected. It was assumed, that "attractive" economic activities will be those, where calculated FDI intensity ratios will be the highest; and vice versa, "unattractive" economic activities will be those, where FDI intensity ratios will be the lowest. To benchmark, it is assumed that attractive economic activities are those, which amount to the ratio of FDI intensity higher than $21 \%$. In order to decide which activities amount to higher than $21 \%$ intensity ratios, we look at the end of the period 2006. The "attractive" activities, according to calculations of the year 2006 are: financial intermediation (181.15\%); electricity, gas and water supply (48.68\%); manufacturing (77.76\%); mining and quarrying (53.59\%); transport, storage and communications (post and telecommunications) $(47.73 \%)$; wholesale and retail trade; repair of motor vehicles, motorcycles and personal and household goods $(29.17 \%)$; hotels and restaurants $(29.03 \%)$; real estate, renting and business activities $(28.17 \%)$. Other economic activities were considered as being "unattractive". They are: other community, social and personal

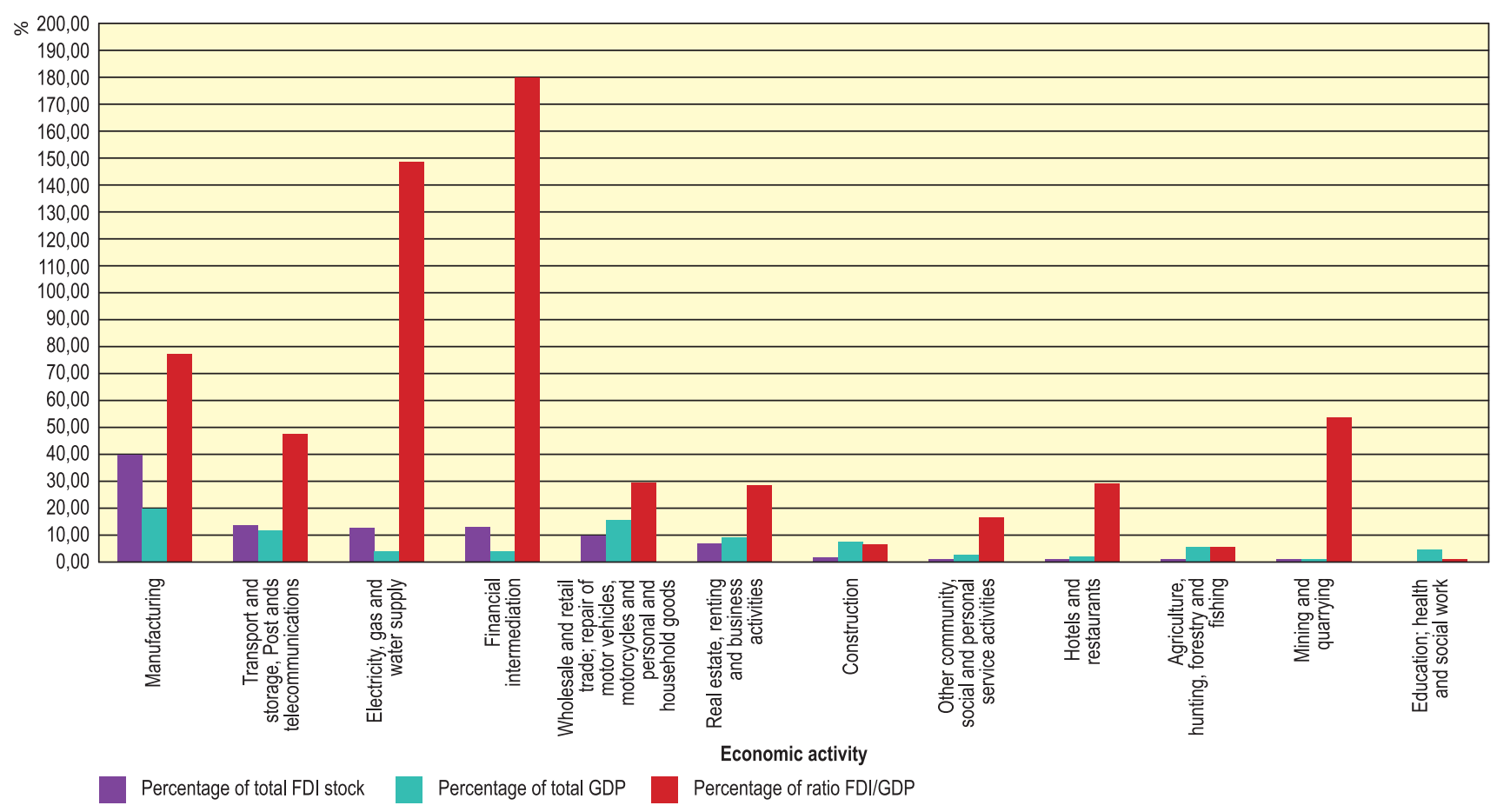

Fig. 1. Juxtaposition of data on FDI stock, GDP and FDI/GDP ratio in Lithuania in the year 2006 
service activities (15.89\%); construction (6.55\%); agriculture, hunting, forestry and fishing (5.46\%); education; health and social work $(0.74 \%)$. While the results of the previous assumption tested by correlation analysis indicated positive and strong FDI impact on economic growth, it is important to find out when the relationship between FDI and economic growth is the strongest.

It was assumed that FDI directed into "attractive" economic activities would influence output in these economic activities more if compared respectively to the impact of FDI in "unattractive" activities on growth of the latter. The premise was tested with a help of correlation-regression analysis. The independent variables of the analysis were divided into two groups: "attractive" economic activities (financial intermediation; electricity, gas and water supply; manufacturing; mining and quarrying; transport, storage and communications; wholesale and retail trade; repair of motor vehicles, motorcycles and personal and household goods; hotels and restaurants; real estate, renting and business activities), and "unattractive" economic activities (other community, social and personal service activities; construction; agriculture, hunting, forestry and fishing; education; health and social work). The gross domestic product of appropriate activity was denoted as dependent variable of the analysis. The results of the correlation-regression analysis indicated that positive correlation coefficients were estimated in almost all attractive economic activities except hotels and restaurants sector (Table 1).

However, the calculated t statistics was higher than tabulated $\mathrm{t}$ not in all attractive economic sectors (Mining and quarrying t Stat 1.2897 and t tabulated 2.7764, Financial intermediation t Stat. 1.2018, t tabulated 2.7764) Therefore the correlation coefficient was significant only in the following economic sectors: wholesale and retail trade; repair of motor vehicles, motorcycles and personal and household goods, manufacturing, real estate, renting and business activities, transport, storage and communications, electricity, gas and water supply. It means that increasing amount of FDI in those sectors coincide with increase of economic growth. In other "attractive" economic sectors the calculated $t$ statistics was lower than tabulated $t$, therefore the correlation coefficients were not significant. The results indicate that FDI into mining and quarrying and financial intermediation is not the main driving force of sector expansion. The negative correlation coefficient in hotel and restaurant sector is not significant. It could be interpreted as follows: hotel and restaurant sector grows not because of FDI into it.
Table 1. The results of correlation-regression analysis between FDI into specific sector and GDP generated by that sector

\begin{tabular}{|c|c|c|}
\hline \multicolumn{3}{|c|}{ "Attractive" economic activities } \\
\hline & $\mathrm{R}$ & $\mathrm{R}^{2}$ \\
\hline $\begin{array}{l}\text { Wholesale and retail trade; } \\
\text { repair of motor vehicles, } \\
\text { motorcycles and personal and } \\
\text { household goods }\end{array}$ & 0.9966 & 0.9933 \\
\hline Manufacturing & 0.9797 & 0.9597 \\
\hline $\begin{array}{l}\text { Real estate, renting and business } \\
\text { activities }\end{array}$ & 0.9698 & 0.9405 \\
\hline $\begin{array}{l}\text { Transport, storage and } \\
\text { communications }\end{array}$ & 0.9511 & 0.9046 \\
\hline Electricity, gas and water supply & 0.8905 & 0.7929 \\
\hline Mining and quarrying & 0.5419 & 0.2937 \\
\hline Financial intermediation & 0.5151 & 0.2653 \\
\hline Hotels and restaurants & -0.2512 & 0,0631 \\
\hline \multicolumn{3}{|c|}{ "Unattractive" economic activities } \\
\hline & $\mathrm{R}$ & $\mathrm{R}^{2}$ \\
\hline Construction & 0.9816 & 0.9636 \\
\hline $\begin{array}{l}\text { Other community, social and } \\
\text { personal service activities }\end{array}$ & 0.8607 & 0.7408 \\
\hline $\begin{array}{l}\text { Agriculture, hunting, forestry } \\
\text { and fishing }\end{array}$ & 0.8505 & 0.7234 \\
\hline $\begin{array}{l}\text { Education; health and social } \\
\text { work }\end{array}$ & -0.6020 & 0.3623 \\
\hline
\end{tabular}

The coefficients of determination $R^{2}$ were strong in five "attractive" economic sectors. The results of correlation-regression analysis in "unattractive" economic activities did no support the hypothesis, because positive and significant correlation coefficients were observed both in "attractive" and in "unattractive" economic activities (except the case of hotels and restaurants sector and education, health and social work sector). The highest correlation coefficient was detected in "attractive" 
economic activity. However, other positive and significant correlation coefficients estimated in "unattractive" activities (other community, social and personal service activities; and agriculture, hunting, forestry and fishing sectors), were lower than significant correlation coefficients in "attractive" economic activities.

\section{FDI intensity by economic activity and GDP, created by one enterprise of that economic activity}

We want to recall that in the very beginning of the research the relationship between cumulative FDI and economic growth was estimated. Economic growth was expressed in terms of GDP. Later we took a closer look at sectors of economy and checked the relationship between FDI into specific economic activity and GDP generated in that activity. Now we are sequentially going into even enterprise level. Our purpose is to find out if there is a relationship between the FDI intensity in specific economic activity and GDP, created by one enterprise of that economic activity. We assume, that the highest shares of GDP for one sector's enterprise are created in the sectors, which contain the highest FDI intensity ratios.

Fig. 2 indicates that the highest amounts of calculated ratios during the last three years (2004-2006) were estimated in "attractive" economic sectors: financial intermediation, electricity, gas and water supply, mining and quarrying, manufacturing. However, other sectors, which were denoted as "attractive" (wholesale and retail trade; repair of motor vehicles, motorcycles and personal and household goods; hotels and restaurants; real estate, renting and business activities), had lower GDP per enterprise ratios. Some "unattractive" activities, e.g. agriculture, hunting, forestry and fishing, and construction had even surpassed "attractive" economic activities.
Our assumption was supported because the highest shares of FDI per enterprise were calculated in the same economic activities, where FDI intensity ratios were the highest. These activities are: financial intermediation; electricity, gas and water supply; mining and quarrying; manufacturing. Meanwhile, one of the lowest shares of GDP per enterprise were calculated in "unattractive" economic activities. Generalizing the indicated phenomenon we claim that concentration in more "attractive" from FDI point economic activities might be related to hidden process of crowding out local enterprises.

\section{Conclusions}

Analysis of various sources of literature indicated, that most countries and governments tend to attract FDI because of emphasis on positive aspects of FDI. FDI usually is treated as additional source of capital and generator of new job places. Spillovers of new technologies are supposed to be undisputable and increase of exports is seen as natural consequence. Nevertheless, some scientists point out plausible negative effects of FDI: the repatriation of profits; crowding out of domestic companies; adding up to inflation rate and increase of negative trade balance.

Seeking to detect FDI effects on Lithuanian economy on the whole, and on separately taken economic activities, correlation analysis has been applied. Originality of presented research lies in the devised by authors approach to characterization of economic activities. The criterion of "FDI intensity" has been introduced. The FDI intensity in the context of elaborated research was presented as ratio of FDI stock generated by economic activity to GDP at current prices by economic activity, and expressed in percentage terms. Afterwards, the characteristics of ,attractive“, and „unattractive“

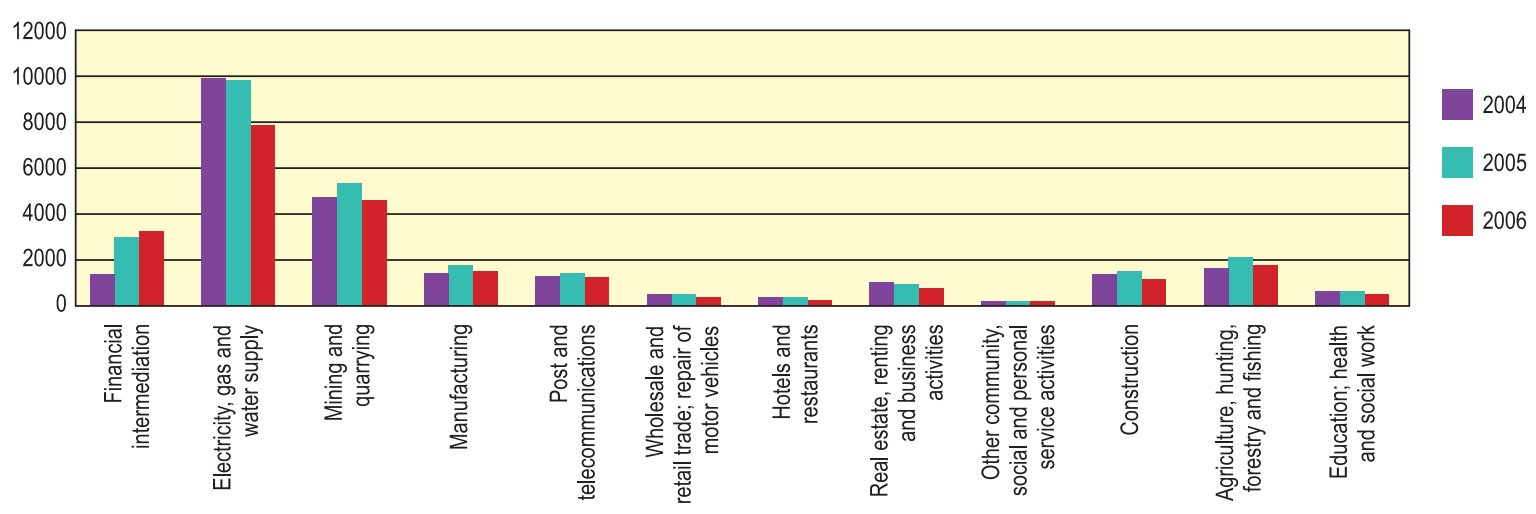

Fig. 2. Ratio of GDP of specific economic activity to number of enterprises operating in that economic activity (indicates GDP per company in considered economic activities) 
economic activities in terms of FDI were defined. Performed analysis let us reveal that "attractive" economic activities with higher FDI intensity are characterized by higher GDP per enterprise compared to "unattractive" in terms of FDI activities.

To generalize, the main practical conclusions are as follows.

- First, foreign direct investment affects Lithuanian economic growth, a strong positive relationship between FDI stock and GDP growth exists.

- Second, positive, negative, significant and insignificant correlation coefficients were determined both, in "attractive" and "unattractive" from FDI point economic activities. Taking into account, that positive and significant correlation coefficients prevail, it might be stated that FDI, in principle, impacts majority of economic activities, only extent of that impact differs.

- Third, more "attractive" economic activities with higher FDI intensity display higher concentration. The latter observation leads to assumption about crowding out of local companies from FDI intensive economic activities in Lithuania.

Obtained results are consistent with theoretical simulations: Lithuania, as transition country experiences positive and negative effects of globalization, only positive ones are more vivid and can be traced by employing statistical analysis. Negative effects are more tacit but still should be taken into account in the process of state economic policy formulation.

\section{References}

ALFARO, L. (2002) Foreign direct investment and growth: Does the sector matter? [Looked on 2007-01-18]. Available from Internet: <http:/www.grips.ac.jp/teacher/oono/hp/ docu01/paper14.pdf $>$.

BALASUBRAMANYAM, V. N.; SALISU, M.; SAPSFORD, D. (1999) Foreign direct investment as an engine of growth. Journal of International Trade \& Economic Development, March, 8, 1, p. 27.

BASU, P.; CHAKRABORTY, C. and REAGLE, D. (2003) Liberalization. FDI, and growth in developing countries: A panel cointegration approach'. Economic Inquiry, 41 (3), p. $510-516$

BENGOA, M.; and SANCHEZ-ROBLES, B. (2003) Foreign direct investment, economic freedom and growth: new evidence from Latin America. European Journal of Political Economy, 19, p. 529-545.
BHAGWATI, J. N. (1973) The theory of immiserizing growth: Further applications. In M. B. Connolly and A. K. Swoboda, eds. International Trade and Money. Toronto: University of Toronto Press, p. 45-54.

BORENSZTEIN, E.; DE GREGORIO, J. and LEE, J.-W. (1998) How does foreign direct investment affect economic growth. Journal of International Economics, 45, p. $115-135$.

BROUTHERS, L. E.; WERNER, S.; WILKINSON, T. (1996) The aggregate impact of firms' FDI strategies on the trade balances of home countries. Journal of International Business Studies, 27 (2), p. 359-373.

CHOE, J. I. (2003) Do foreign direct investment and gross domestic investment promote economic growth? Review of Development Economics, February, 7 (1), p. 44-57, 14.

DE MELLO, L. R. (1997) Foreign direct investment in developing countries and growth: a selective survey. Journal of Development Studies, 34 (1), p. 1-34.

DE MELLO, L. R. (1999) Foreign direct investment-led growth: evidence from time series and panel data. Oxford Economic Papers, 51, p. 133-151.

DRABEK, Z.; GRIFFITH-JONES, S. (2007) Managing capital flows in transition economies with a case study of central and eastern europe. World trade organization - economic research and analysis division. [Looked on 2007-01-12]. Available from Internet: <http://www.wto.org/english/res_e/ reser_e/pera9804.doc]>.

HIRCHMAN, A. (1958) The strategy of economic development. New Haven: Yale University Press. 251 p.

KARBASI, A.; MOHAMADI, E.; GHOFRANI, S. (2005) Impact of foreign direct investment and trade on economic growth-12th annual conference [Cairo, $19^{\text {th }}-21$ th of December 2005] [Looked on 2007-01-10]. Available from Internet: $<$ http://www.erf.org.eg/12thAnnualConference/TRADE/ background/Karabasi\&Mohamadi\&Ghofrani.pdf $>$.

Lithuanian Department of Statistics. Available f from Internet: $<$ http://www.stat.gov.lt $>$.

OLOFSDOTTER, K. (1998) Foreign direct investment, country capabilities and economic growth. Weltwirtschaftliches Archiv, 134 (3), p. 534-547.

PREBISCH, R. (1968) Development problems of the peripheral countries and the terms of trade. In James D. Theberge, ed. Economics of Trade and Development. New York: John Wiley and Sons Inc.

SINGER, H. W. (1950) The distribution of gains between investing and borrowing countries. American Economic Review, 40, p. 473-480.

ZHANG, K. H. (2001) Does foreign direct investment promote economic growth. Evidence from East Asia and Latin America. Contemporary Economic Policy, 19 (2), p. $175-185$. 